\title{
Traffic Accident Data Analysis at Section from Sarai Khawaja to Old Faridabad of New Nh-44 (Old Nh-2) Including Bypass in Harayana Using GIS
}

\author{
Sandeep Tewatia
}

Department of Civil Engineering, MVN University, Palwal, Haryana, India

\section{ABSTRACT}

The main object of this study is to discuss the present state of traffic accident information of study area (Area under Old Faridabad and Sector-31 Faridabad Police station). It shall discuss the Identification of high rate accident locations and safety deficient areas on the highway by analysing accident data bank for the study area extracted from Police FIR records for the year 2015 to 2018 with the help of GIS software. The Severity index of every accident is calculated using proportionate weightage of fatal, serious injury, minor injury and property damage only and Severity Index is used in spatial analysis. Eleven numbers of black spot locations have been identified and ranked on NH-44 section (old NH-2) including bypass in Faridabad, Haryana. Also, various remedial measures to those accidental locations (Black Spots) have been suggested.

Keywords : GIS, Black Spot, Severity, Fatal, Injury, Property Damage, Kernel Density.

\section{INTRODUCTION}

\section{Road Safety Situation in India}

The Global status report on road safety 2018 estimates that more than 1,50,785 people are killed in road traffic crashes in India in every year. Approximately half of all deaths on the country's roads are among vulnerable road users - motorcyclists, pedestrians and cyclists. A heterogeneous traffic mix that includes high-speed vehicles sharing the road space with vulnerable road users as well as unsafe road infrastructure and vehicles that are in poor condition all contribute to the high fatality rates seen on India's roads. India is one of the countries included in the Bloomberg Philanthropies Global Road Safety Programme which is being conducted by a consortium of international partners together with national governments and local organizations. In 2017, a total of 1,34,796 fatal accidents were reported which is lower than the 2016 reported figure of $1,36,071$. These fatal accidents had claimed 1,47,913 lives in 2017 as against 1,50,785 in 2016.

Major parameters of road accident statistics in India from 2005 to 2017 are given on Table 1.1 below. While the absolute numbers for road accident, fatal accident, fatality and injury are on the decline, the ratios pertaining to fatal accidents and accident severity have been consistently increasing, year after year. 
Table 1.1 : Long-run trend of major parameters of road accident statistics

\begin{tabular}{|c|c|c|c|c|c|}
\hline \multirow{2}{*}{ Year } & \multicolumn{2}{|c|}{ Number of Accidents } & \multicolumn{2}{|c|}{ Number of Persons } & \multirow{2}{*}{$\begin{array}{l}\text { Accident } \\
\text { Severity* }\end{array}$} \\
\hline & Total & Fatal & Killed & Injured & \\
\hline 2005 & $4,39,255$ & $83,491(19.0)$ & 94,968 & 465282 & 21.6 \\
\hline 2006 & $4,60,920$ & $93,917(20.4)$ & $1,05,749$ & $4,96,481$ & 22.9 \\
\hline 2007 & $4,79,216$ & $1,01,161(21.1)$ & $1,14,444$ & $5,13,340$ & 23.9 \\
\hline 2008 & $4,84,704$ & $1,06,591(22.0)$ & $1,19,860$ & $5,23,193$ & 24.7 \\
\hline 2009 & $4,86,384$ & $1,10,993(22.8)$ & $1,25,660$ & $5,15,458$ & 25.8 \\
\hline 2010 & $4,99,628$ & $1,19,558(23.9)$ & $1,34,513$ & $5,27,512$ & 26.9 \\
\hline 2011 & $4,97,686$ & $1,21,618(24.4)$ & $1,42,485$ & $5,11,394$ & 28.6 \\
\hline 2012 & $4,90,383$ & $1,23,093(25.1)$ & $1,38,258$ & $5,09,667$ & 28.2 \\
\hline 2013 & $4,86,476$ & $1,22,589(25.2)$ & $1,37,572$ & $4,94,893$ & 28.3 \\
\hline 2014 & $4,89,400$ & $1,25,828(25.7)$ & $1,39,671$ & $4,93,474$ & 28.5 \\
\hline 2015 & $5,01,423$ & $1,31,726(26.3)$ & $1,46,133$ & $5,00,279$ & 29.1 \\
\hline 2016 & $4,80,652$ & $1,36,071(28.3)$ & $1,50,785$ & $4,94,624$ & 31.4 \\
\hline 2017 & $4,64,910$ & $1,34,796(29.0)$ & $1,47,913$ & $4,70,975$ & 31.8 \\
\hline
\end{tabular}

* Number of persons killed per 100 accidents.

Serious injuries even at low velocity crashes, unlike car occupants who are protected by impact. It is clear for the above number of accidents are increasing every year. It is very necessary to develop new techniques with the help of latest technology such as GIS, latest software etc. to reduce accidents. Simultaneously in India it is very necessary to improve accident data collection techniques, a lot of research work is required to improve present condition of our country.

\section{OBJECTIVE \& SCOPE}

\subsection{Objective}

The objective of the study is to make an assessment of accident pattern considering spatial temporal aspects and identification of black spots in study area using
Geographical information system (GIS). Also, accidents have been analysed in following manner:

$\checkmark \quad$ Road accident data analysis for study area

$\checkmark \quad$ Identification of Black Spot location using GIS from Sarai Khawaja to Old Faridabad on NH-

2 (old) section including Bypass lying in study area

$\checkmark \quad$ Identify various cause of accidents

$\checkmark$ Kernel density analysis of accident data using Arc GIS

$\checkmark \quad$ Various steps to avoid accidents

The outcome of this study will help in reducing accidents by providing suitable measure as per black spot locations. 


\subsection{Scope of the project}

The study includes the GIS application in identifying black spot locations in study area on highways in Haryana. The scope of the study has been divided into two parts. First part of study covers accident data analysis and finding out various conclusions based on these analyses. Other part of study covers calculation of Severity index based on accident data and identification of black spots Locations using Arc GIS software. The conclusions and recommendations are suggested based on black spot identification as well as accident data analysis.

\section{LITERATURE REVIEW}

Road traffic system can be described as a man machine environment with a complexity of factors involved. The basic interacting components at the micro level are the road user, the vehicle and the road. Some of the accidents related studies carried out in India have been discussed in the following section.

Srinivasan et. al, (1987) studied on scientific identification and improvement of accidentprone locations on National Highways in Kerala State. The study has three alternative methods for detection of black spots. The methods are given as follows:

(i) Quantum of Accident

(ii) Accident Prone Index

(iii) Weighted Severity Index

\section{(i) Quantum of Accident Method}

Accidents are mainly caused due to improper interventions among various factors related to drivers, vehicles, roads and weathering conditions. If more than three accidents occurred on one short section of a road, there are all grounds to believe that road conditions are creating accident situations. All the stretches registering nine or more accidents for three years are taken as accident-prone stretches. Identification of accident-prone stretches based on quantum of accident was carried out by taking all the stretches, which have nine or more accidents during the three years period.

\section{(ii) Accident Prone Index}

For the accident-prone index the following three components of accidents have been considered.

a) Consistency - It means how frequently accidents are taking place. Accidents may occur every year or one in two or more years. If accidents are being caused every year on any part of the road, the part of the road should be taken as more accident prone.

b) Tendency- It means the number of accidents is increasing continuously or irregularly or it is content. If any part of the road is showing increasing trend that part of the road is more accident-prone.

c) Level -It means the magnitude of accidents is quantitative terms. More the number of accidents during a specified period, the higher are the accident proneness of that part of the road.

\section{(iii) Weighted Severity Index (WSI)}

Under the weighted severity index method, casualties have been divided into three group's i.e. (i) fatal, (ii) grievous injury, (iii) simple injury. Based on the cost of accidents fatalities were given a weight of fifteen points, grievous injuries a weight of nine points and simple Injuries a weight of one point.

Vaishnav et. al, (1997) studied on Gujarat, is the most developed state in India in Industrial and Agriculture. Road accident growth rate depends on industrial and commercial activities and level of vehicle ownership rate. The state of Gujarat has a high vehicle owner ship rate of 454 motor vehicles 
per 10,000 populations. It was seen that during 1991 , total No. of road accidents were 2693 in Gujarat state, out of which 5957 road accidents took place only on entire National Highways of state consisting 888 No. of fatal road accidents.

Sarin, S.M., (1998) has carried out studies regarding the analysis of age wise fatalities $\mathrm{m}$ metropolitan cities of India. It reveals that majority of the road accidents victims fall $m$ the age-group of 15-39 years (around 50 percent to 65 percent) followed by 40-59 (between 20 to 30 percent) in the age group 15 to 59 years are the most vulnerable. Premature deaths due to road accidents cause huge economics loss to the country. The highest road traffic fatalities observed in the economic loss to the country. The highest road traffic fatalities observed in the age group 15-39 years may be because the drivers of this age group are comparatively inexperienced, somewhat aggressive and also have higher exposure levels. There is need to frame some educational measures for these age-group people.

Kumar, M.B., (1999) developed a rational approach for accident analysis and road safety in Delhi. In India annually more than 70,000 people are losing their lives due to accidents and these amounts to $25 \%$ of the total deaths in the developing world. Further about $15 \%$ of these accidents are occurring in urban areas of the country. As per the available about 2000 persons are getting killed in Delhi alone. Due to the gravity of the situation many efforts have been attempted in past to minimize these road accidents and it is felt to study accident characteristics. For developing remedial measures, through understanding of the accident characteristics in present is essential.

Kernel density Estimation (KDE) is suggested as a method for identifying hazardous location considering crash severity and spatial interactions. To apply this method, we need to give attention to two parameters which determine the shape of kernel density; bandwidth and the function $\mathrm{K}$, called a "kernel". While bandwidth means a horizontal range of accident likelihood, kernel means the magnitude of risk at each location in the range. That is to say, bandwidth and kernel can be regarded as a horizontal element and a vertical element, respectively. Conceptually, the kernel function divides study area into small cells defined by users and then, calculate cell values which are highest at the locations of the point, diminish away from the points, and finally reach zero at the radius distance from the points. A location having a high cell value can be identified as a hazardous location and thus we can obtain different results compared to the results based on crash frequency. The other parameter, bandwidth means the influential range to outbreak of a crash. In this article, a bi-level method is suggested, which identifies hazardous areas at wide scale and then determine exact locations or segments at narrow scale.

\section{METHODOLOGY}

\subsection{Methodology of Study}

In order to perform analysis related to road accident, a spatial database incorporating all the desired Information be created. First of all, the existing road network was extracted from guide map. The updating of road network was carried out with the help of Satellite data from Google earth. All this information was registered on to a single layer and verified through satellite. Small discrepancies in road discontinuities were resolved by edge matching and proper editing in order to achieve a seamless digital database. The non-spatial data related to accident records available from police records were attached to the spatial data layers. A proper integration of the spatial and non-spatial was carried out by using Arc Map (GIS) version 10.4 Software. Sufficient care was taken to ensure that the database remained dynamic, 
so that any change in attribute database was reflected in the GIS spatial layers using the Arc Map (GIS) version 10.4 Software as the base, customized query for analysis of road accident data were defined. The methodology adopted is showing through flow chart in figure 4.1 .

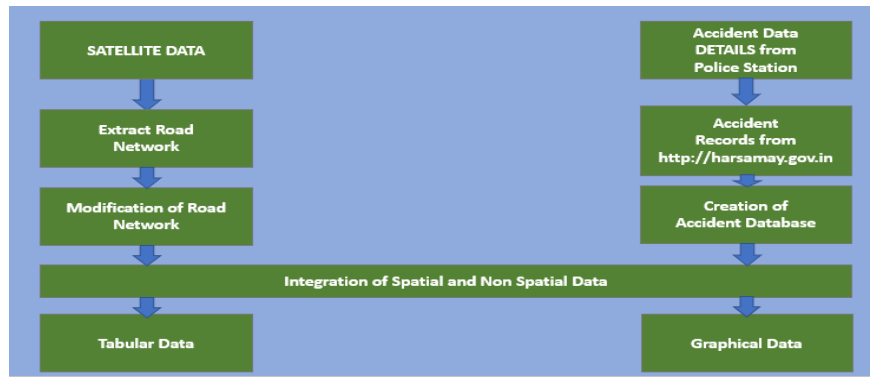

Figure Error! No text of specified style in document..1. Flow chart showing the methodology adopted

\section{SALIENT FEATURES OF STUDY AREA}

\subsection{Study area}

Area under Old Faridabad and Sector-31 Faridabad Police station in Faridabad district of Haryana in northern India which is 03 kilometres from the national capital New Delhi has been chosen as study area for accident data analysis and its representation. The area is lying between two major parallel roads NH-44 (Old NH-2) and Faridabad Bypass passes through these areas. Section from Sarai Khawaja to old Faridabad of new NH-44 (OLD NH-2) which is major connecting route for important cities Gurgaon, Ballabhgarh, Noida and Delhi) passes through study area. Beside all these features study area is mainly famous for road side Malls, Surajkund mela etc. which attract a lot of traffic from nearby areas.

Vehicle accident has been collected from Haryana police station web site as well as from Old Faridabad and Sector-31 Faridabad police station for 2015 to 2018. Base map is taken from Arc GIS and satellite imagery is taken from Google earth.
The location map of Study Area is shown in Figure 5.1
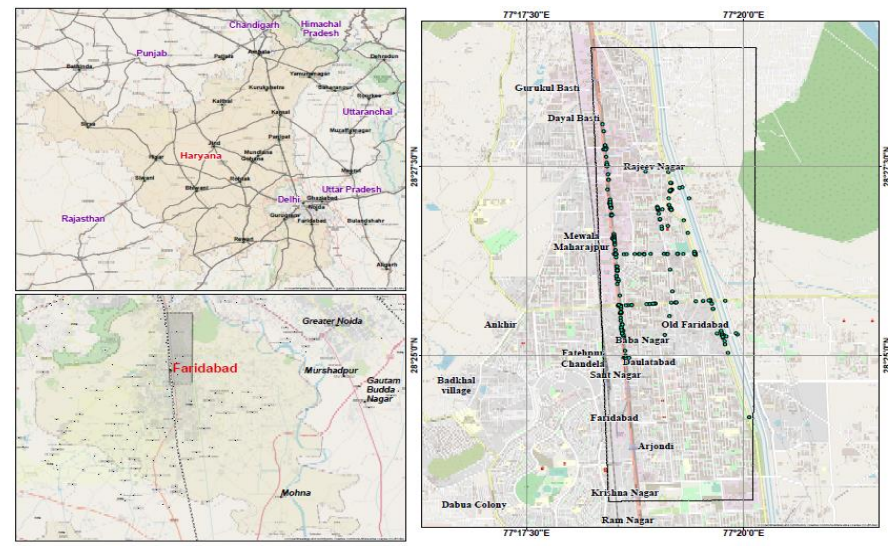

Figure Error! No text of specified style in document..1. Location Map of Study Area

\section{IDENTIFICATION OF BLACK SPOT}

\section{Study Area}

The study area for Identification of black spot is Area under Old Faridabad and Sector-31 Faridabad police station. The area is lying between two major parallel roads NH-44 (Old NH-2) and Faridabad Bypass passes through these areas. Section from Sarai Khawaja to old Faridabad of new NH-44 (OLD NH-2).

\section{Methodology}

The methodology has been subdivided in to the following steps

Collection of accidents data with Spatial coordinates at each location of study area

\section{Use Google Earth Map}

Load vehicle crash data and aggregate the data at each location.

Compute a severity index at each location

Create a vehicle accidents black spot map with Kernel Density Estimation. 
> Compute severity indices and rank of unsafe black spot

ArcGIS software with the spatial statistic toolbox is used for mapping and spatial analysis.

> Collection of accidents data: Vehicle accidents data of each location of study area has been section collected from Haryana Police website.

\section{Compute a severity index at each location}

The severity index is computed by the following equation:

Severity Index SI $=6.0 \times \mathrm{X} 1+3 \times \mathrm{X} 2+0.8 \times \mathrm{X} 3+0.2 \mathrm{x}$ $\mathrm{X} 4$

Where $\mathrm{X} 1$ = total number of fatal injury accidents

$\mathrm{X} 2=$ total number of serious injury accidents

$\mathrm{X} 3=$ total number of minor injury accidents

$\mathrm{X} 4$ =total number of property damage only accidents

The severity index is used as the criteria for spatial analysis in this study. The Severity Index of the individual accident evaluated according as collected accident data for the Kernel Density Estimation.

Create a vehicle accidents black spot map with Kernel Density Estimation

The locations of black spots have been basis of the Kernel density. The spatial coordinate of black spot's location has worked out with the help of prepared Kernel Density map. Kernel Density Estimation with Google map and Google Satellite map is shown in figure 6.1. The ranking of black spots also has been assigned based on the Kernel Density.
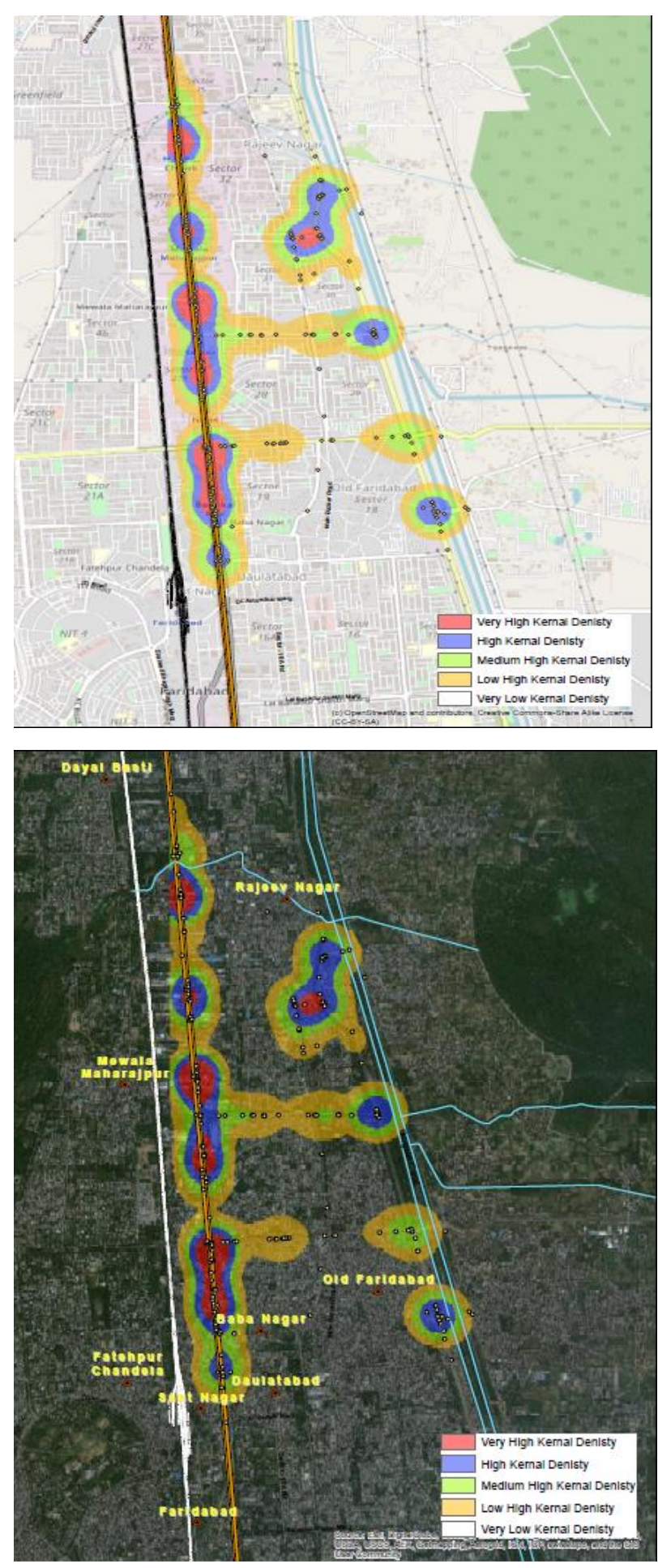

Figure Error! No text of specified style in document..1 Kernel Density Estimation with Google map and Google Satellite map

\section{Severity indices and rank of Black spot}

By using ArcGIS Kernel Density Estimate has been done. With the help of density map frame radius 200 
and cell radius value of 50 the ranking of black spot on study area has been identified based on kernel density severity indices. Identified spot locations with ranking are shown in table 6.1.

Table Error! No text of specified style in document..1 Severity indices and rank of Black spot

\begin{tabular}{|l|l|l|l|}
\hline $\begin{array}{l}\text { SI. } \\
\text { No. }\end{array}$ & Location & Spatial Location & Ranking \\
\hline 1 & $\begin{array}{l}\text { Old Faridabad Chowk, Mathura } \\
\text { Road }\end{array}$ & $28.415736^{\circ}, 77.310794^{\circ}$ & 9 \\
\hline 2 & Badhkal Chowk & $28.423436^{\circ}, 77.309986^{\circ}$ & 1 \\
\hline 3 & Sector-28 Metro Station & $28.438947^{\circ}, 77.308837^{\circ}$ & 4 \\
\hline 4 & Mewla Maharajpur, Faridabad, & $28.442478^{\circ}, 77.308236^{\circ}$ & 2 \\
\hline 5 & Sahni Chowk, Faridabad & $28.450703^{\circ}, 77.307775^{\circ}$ & 6 \\
\hline 6 & NHPC Metro Station, Faridabad & $28.458756^{\circ}, 77.307159^{\circ}$ & 3 \\
\hline 7 & NHPC Chowk Mathura Road & $28.436267^{\circ}, 77.309047^{\circ}$ & 3 \\
\hline 8 & Sharmik Vihar, Bypass Road & $28.439512^{\circ}, 77.323947^{\circ}$ & 5 \\
\hline 9 & Police Line, Sector-30, Faridabad & $28.443664^{\circ}, 77.322667^{\circ}$ & 8 \\
\hline 10 & Sector-29, Bypass Road & $28.428792^{\circ}, 77.326903^{\circ}$ & 10 \\
\hline 11 & Kheri Pul, Bypass Road & $28.422017^{\circ}, 77.329043^{\circ}$ & 7 \\
\hline
\end{tabular}

\section{VII.RESULTS AND DISCUSSION}

Area under Old Faridabad and Sector-31 Faridabad Police station in Faridabad district of Haryana in northern India which is 03 kilometres from the national capital New Delhi has been chosen as study area for accident data analysis and its representation. The area is lying between two major parallel roads NH-44 (Old NH-2) and Faridabad Bypass passes through these areas. Section from Sarai Khawaja to old Faridabad of new NH-44 (OLD NH-2) which is major connecting route for important cities Gurgaon, Ballabhgarh, Noida and Delhi) passes through study area.

\section{Fatal Accidents}

The number of fatal accidents is shown figure 7.1 in study area from Year 2015 to Year 2018.

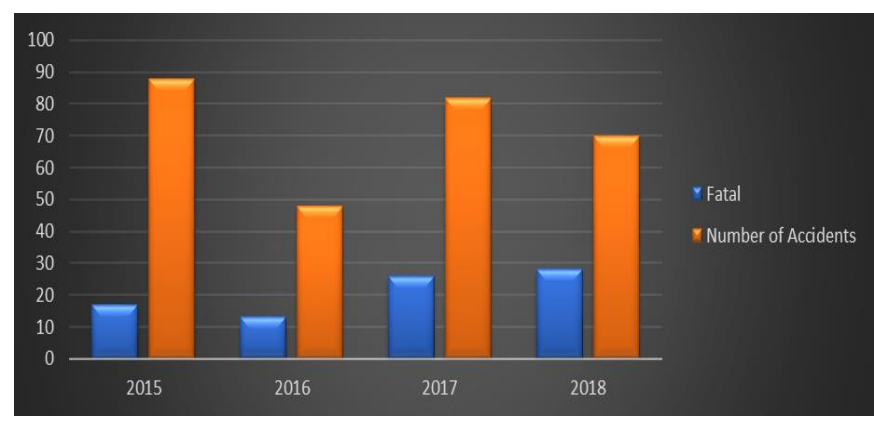

Figure Error! No text of specified style in document..1: Fatal accidents in study area

\section{Percentage of Fatal Accidents}

The percentage of fatal accidents are shown in figure 7.2 in study area from Year 2015 to Year 2018. 


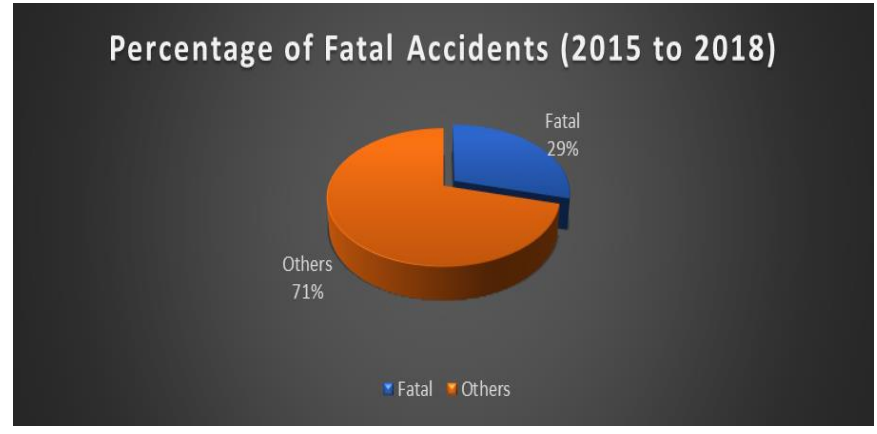

Figure Error! No text of specified style in

document..2 : Percentage of Fatal accidents from 2015 to 2018 in study area

Overall Percentage of fatal accident from 2015 to 2018 is $40 \%$ which is quite high and directly indicates that Road safety condition is very poor. From year 2015 to 2018, month wise distribution of accidents in Study area is as under:

\section{Month wise accidents details from 2015 to 2018}

The month wise number of accidents are shown in figure 7.3 in study area from Year 2015 to Year 2018.

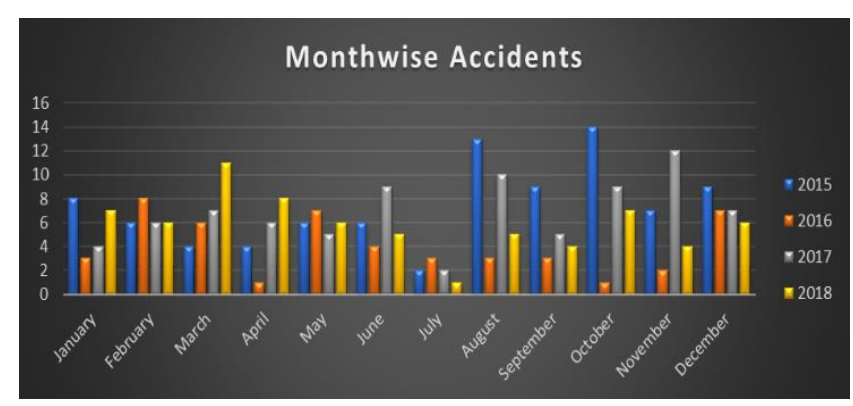

Figure Error! No text of specified style in document..3 : Month wise accidents details from 2015 to 2018

\section{Vehicle wise accidents data distribution}

The vehicle wise accidents are shown in figure 7.4 in study area from Year 2015 to Year 2018.

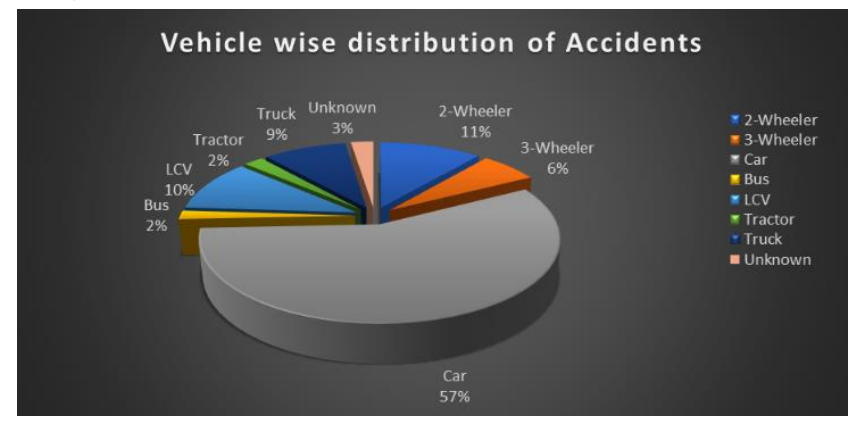

Figure Error! No text of specified style in document..4 : Vehicle wise accidents data distribution from 2015 to 2018

\section{Time slot wise data distribution}

The time slot wise accidents distribution is shown figure 7.5 in study area from Year 2015 to Year 2018.

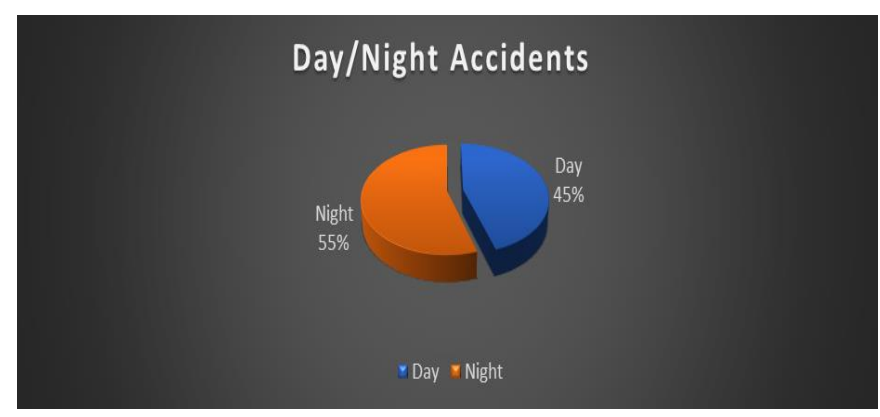

Figure Error! No text of specified style in document..5: Day/Night accidents data distribution from 2015 to 2018

\section{Distribution of Pedestrian Accidents}

The distribution of numbers of pedestrian accidents are shown in figure 7.6 and in study area from Year 2015 to Year 2018.

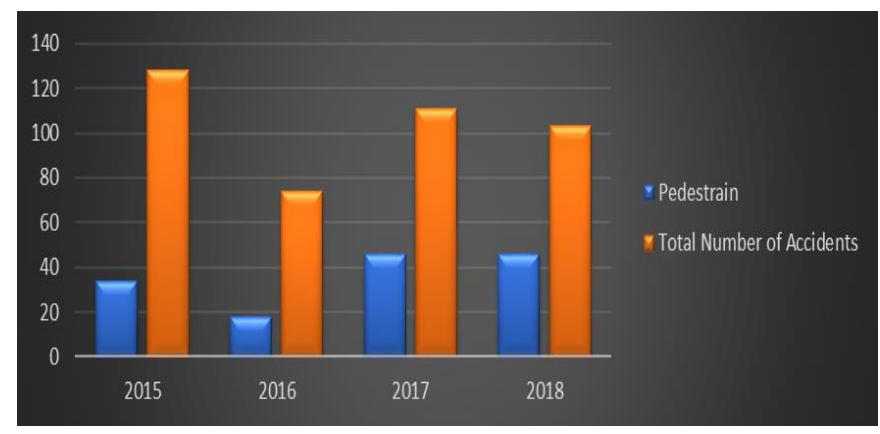

Figure Error! No text of specified style in document..6: Number of Pedestrian Accidents

The percentage share of pedestrian accidents is shown in figure 7.7 from Year 2015 to Year 2018. 


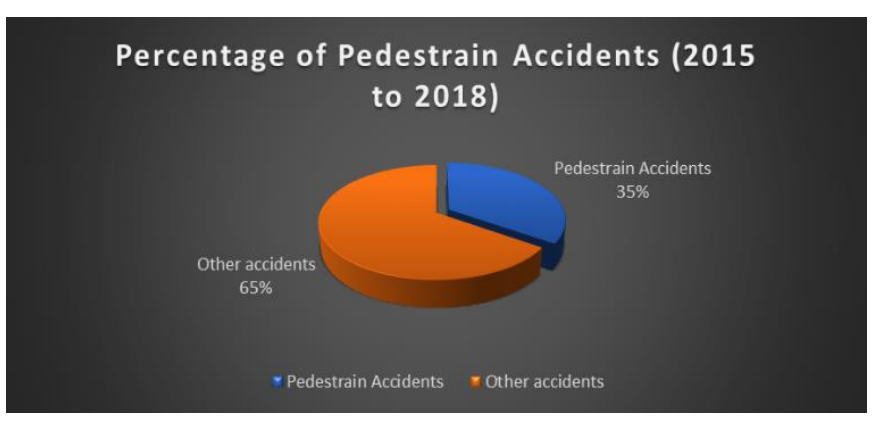

Figure Error! No text of specified style in document..7: Total Share of Pedestrian Accidents from 2015 to 2018

\section{CONCLUSIONS \& RECOMMENDATIONS}

\section{Conclusions}

Road accidents attributable to various types of traffic rules violations reveals that over speeding constitutes the main violation associated with accidents.

From the present study the following conclusions has been drawn:

1) From traffic data analysis it is evident that Cars are involved in more than $55 \%$ of accidents. In this period, three numbers of flyover have constructed at location Old Faridabad chowk, Badkhal Chowk and NHPC Chowk simultaneously and one number of underpass has constructed Mewla Maharajpur Chowk.

2) In the study area there is no facility for pedestrian due to this reason involvement of pedestrians in accident is quite high. Accident analysis shows that pedestrian is involved in 35 $\%$ of accidents. During Year 2018, foot over bridge has constructed near Mewla Maharajpur chowk and Old Faridabad on NH-44.

3) Kernel density analysis shows that there are 11 black spots in study area on NH-44 including Faridabad Bypass section having $5 \mathrm{~km}$ length on NH-44. All these locations are junctions: Old Faridabad Chowk, Badhkal Chowk, Sector28 Metro Station, Mewla Maharajpur Chowk, Sahni Chowk, NHPC Metro Station, NHPC
Chowk, Sharmik Vihar, Bypass Road, Police Line, Sector-30-Bypass Road, Sector-29, Bypass Road, Kheri Pul, Bypass Road.

\section{Recommendations}

1) Study area shows higher percentage accidents by Cars, LVC, and Trucks at junction crossing in median opening, it is recommended to provide Grade Separated Section at following locations:

a) Vehicular underpass at Sharmik Vihar on Bypass Road

b) Vehicular underpass at Sector-30 Police line Chowk on Bypass Road

c) Flyover at Sector-29/Badkhal Marg/Greater FBD Chowk on Bypass road

d) Flyover at Kheri Pul Chowk on Bypass road

2) Study area shows higher percentage of pedestrian accidents, it is recommended to provide Foot over bridges at following locations:

e) Between Badkhal and Old Faridabad Chowk on NH-44 near DPS School.

f) Near NHPC Chowk on NH-44

g) Between Atmadpur Chowk and IP Colony on Bypass Road

3) Percentage of Fatal accidents is $29.2 \%$. With increase in vehicular speed fatality of accidents increases and hence to avoid fatal accidents application of clamming measures to reduce the speed of vehicle is advisable.

4) Other alternative to avoid accidents are:

a) Median opening should be widened so that a vehicle can stop at median gap during crossing on Bypass Road. 

b) U turn with acceleration and deceleration lane should be provided at Junctions.
c) Rumble strips should be provided on minor roads of junctions.

\section{REFERENCES}

[1]. Srinivasan, N.S., Lyer, V.S., Mahesh Chand \& Srinath, K., 1987, "Scientific Identification and Improvement of Accident Prone Location on National Highways in Kerala", Journal of Indian Road Congress, Vol. 48, No.3.

[2]. Dhir, M.P. \& Sarin, S.M., 1993, "Some Special Features on Traffic safety Situations in India", Proc. Int., Conf. on Road safety in Two Continents, the Netherlands, VTI Conferences I a Part 1, pp. 16-30.

[3]. Vaishnav, M.J., Parikh, S.J., Bhat, H.K.\& Upadhyay, V.J., 1997," A Macro Level Study of Road accidents on National Highway No. 8-B", Indian Highway, Vol. 25, No.8.

[4]. Sarin, S.M, 1998, "Road Traffic Safety in Indian-Issues and challenges Ahead", Indian Highway.

[5]. Kumar, M. B., 1999, "Development of Rational Approach for Accidents Analysis and Road Safety in Delhi", Unpublished ME Thesis, COTE, Department of Civil Engineering, University of Roorkee, Roorkee.

[6]. Jain, S.S. \& Parida, M., 2001, "Final Report on Development of Scientific Approach to Road Safety for Indian Environment". Report Submitted to AICTE, Department of Civil Engineering, Indian Institute of Technology Roorkee.

[7]. Ghosh S.K., Parida M. and Uraon K.J., "TRAFFIC ACCIDENT ANALYSIS FOR DEHRADUN CITY USING GIS” ITPI JOURNAL 1: 3 (2004) 40-54 www.itpindia.org.
[8]. Implementation G1S-Based Highway Safety Analyses- Bridging the Gap by Richard C, Smith, David L. Harkey and Bobby Harris.

[9]. Analysis of road Traffic Fatality Data for Asia by Dinesh Mohan.

[10]. Saxena A., Ganesh Babu, R. K. Bajpai and S.M. Sarin. 2000. "GIS as an aid identify accidents patterns",

[11]. Using GIS to Identify Pedestrian Vehicle Crash Hot Spots and Unsafe Bus Stops by Long Tien Truong and Sekhar V. C. Somenahalli

[12]. World Health Organization "The Global status report on road safety 2018" https://www.who.int/violence_injury_preventi on/road_safety_status/2018/en/

[13]. Government of India Ministry of road Transport and Highways Transport Research Wing New Delhi "ROAD ACCIDENTS IN INDIA 2016 and 2017"

[14]. http://www.indiaenvironmentportal.org.in/files /file/Road\%20accidents\%20in\%20India\%20201 6.pdf http://www.indiaenvironmentportal.org.in/files /file/road\%20accidents\%20in\%20India\%20201 7.pdf

[15]. Arc Map (GIS) version 10.4 Software

\section{Cite this article as :}

Sandeep Tewatia, "Traffic Accident Data Analysis at Section from Sarai Khawaja to Old Faridabad of New Nh-44 (Old Nh-2) Including Bypass in Harayana Using GIS", International Journal of Scientific Research in Science and Technology (IJSRST), Online ISSN : 2395-602X, Print ISSN : 2395-6011, Volume 6 Issue 3, pp. 87-96, May-June 2019. Available at doi : https://doi.org/10.32628/IJSRST196313 Journal URL : http://ijsrst.com/IJSRST196313 